Dialectologia. Special issue, V (2015), 141-166.

ISSN: 2013-2247

Received 16 May 2015.

Accepted 17 July 2015.

\title{
COMBINING GEOLINGUISTIC SOURCES IN DIALECT SYNTAX: THREE CASE-STUDIES THROUGH ALPI AND CORDIAL-SIN
}

\author{
Maria LOBO ${ }^{1} \&$ Ernestina CARRILHO ${ }^{2}$ \\ CLUNL/FCSH-Universidade Nova de Lisboa ${ }^{1}$ / CLUL/FLUL-Universidade de Lisboa ${ }^{2}$ \\ maria.lobo@fcsh.unl.pt / ernestina.carrilho@campus.ul.pt
}

\begin{abstract}
Although geolinguistic projects do not usually provide adequate (if any) coverage of syntactic variation, current studies of dialect syntax still may benefit from data that were made available in traditional linguistic atlases. Concomitantly, dialect corpora, as a different kind of linguistic resource for the study of nonstandard syntax, often grant access to spontaneous oral data that allow the study of phenomena that are hard to elucidate through traditional questionnaires.

In this paper we present and discuss three morphosyntactic phenomena in European Portuguese varieties, as they appear through both kinds of sources - more specifically, the Atlas Lingüístico de la Península Ibérica (ALPI), a traditional linguistic atlas, and CORDIAL-SIN, a dialect corpus. Through both sources, we will investigate the geolinguistic syntactic variation concerning: (i) the distribution of gerund forms; (ii) the presence of articles before prenominal possessives; and (iii) the distribution of verbal forms ending in -ra.

The contrast and complementarity of both kinds of sources, namely, their advantages and inconveniences, invite us to discuss new methods that integrate complementary methods in collecting data for dialect syntax.
\end{abstract}

\section{Keywords}

dialect syntax, European Portuguese, dialect corpus, linguistic atlas, methodology 


\section{SOBRE A COMBINAÇÃO DE FONTES GEOLINGUÍSTICAS EM SINTAXE DIALECTAL: ESTUDO DE TRÊS}

\section{CASOS A PARTIR DO ALPI E DO CORDIAL-SIN}

\section{Resumo}

Embora os projetos geolinguísticos não forneçam habitualmente uma cobertura adequada da variação sintática, ainda assim os estudos recentes de sintaxe dialetal podem beneficiar de dados disponibilizados nos atlas linguísticos tradicionais. Concomitantemente, os corpora dialetais, um outro tipo de recurso para o estudo da sintaxe não padrão, dão geralmente acesso a dados orais que permitem o estudo de fenómenos difíceis de investigar através de questionários tradicionais.

Neste artigo, apresentamos e discutimos três fenómenos morfossintáticos em variedades do português europeu através destes dois tipos de fontes - o Atlas Lingüístico de la Península Ibérica (ALPI), um atlas linguístico tradicional, e o CORDIAL-SIN, um corpus dialetal. Através destas duas fontes, investigaremos a variação sintática geolinguística relativamente a: (i) distribuição de formas de gerúndio; (ii) presença de artigos antes de possessivos pré-nominais; e (iii) distribuição de formas verbais terminadas em -ra.

O contraste e complementaridade entre estas duas fontes, nomeadamente, as suas vantagens e inconvenientes, levam-nos a destacar a importância da combinação de metodologias complementares para a recolha de dados para o estudo da sintaxe dialetal.

\section{Palavras-chave}

sintaxe dialectal, português europeu, corpus dialetal, atlas linguístico, metodologia

\section{Introduction}

Although geolinguistic projects do not usually provide adequate (if any) coverage of syntactic variation, current studies of dialect syntax still may benefit from data that were made available in traditional linguistic atlases. Concomitantly, as a different kind of linguistic resource for the study of non-standard syntax, dialect corpora often grant access to spontaneous oral data that allow the study of phenomena that are hard to elucidate through traditional questionnaires.

In this paper we present and discuss three morphosyntactic phenomena in European Portuguese varieties, as they appear through two kinds of sources - more specifically, the Atlas Lingüistico de la Península Ibérica (ALPI), a traditional linguistic atlas, and CORDIAL-SIN, a dialect corpus. Through both sources, we investigate the geolinguistic syntactic variation concerning: (i) the distribution of gerund forms; (ii) the 
presence of articles before prenominal possessives; and (iii) the distribution of verbal forms ending in -ra.

By contrasting both kinds of sources, and discussing their advantages and inconveniences, we intend to evaluate the relevance of complementary methods in collecting data for dialect syntax.

The paper is organized as follows: in section 2, we characterize the sources and the methodology for obtaining the data for this study; in section 3, we discuss dialectal variation in the syntactic properties of three morphosyntactic phenomena, comparing data obtained from ALPI and from CORDIAL-SIN - variation in the syntactic properties of gerunds (§3.1), variation in the distribution of determiners before possessives (§3.2), variation in the distribution of verbal forms ending in -ra (§3.3).

\section{Methodology: two kinds of geolinguistic sources}

As mentioned above, in this study we consider two sources: the Atlas Lingüístico de la Península Ibérica (ALPI), a traditional geolinguistic project that includes a morphosyntactic questionnaire besides phonetic and lexical questionnaires, and CORDIAL-SIN, a dialect corpus.

For the first source, we observed the answers given to eleven questions related to the three morphosyntactic phenomena we wanted to investigate, as registered in the fieldwork questionnaires. ${ }^{1}$ We considered only the Portuguese network, comprising 93 localities distributed along mainland Portugal. The enquiries for ALPI were conducted between 1931 and the 1950s (García Mouton et al. 2012: 2). We have also taken into account previous work by Mouzo (2008) on -ra forms using ALPI data.

CORDIAL-SIN is a dialect corpus that includes transcribed samples of spontaneous or semi-directed speech of rural speakers from 42 localities, including not only mainland Portugal, but also the islands of Azores and Madeira. The transcriptions

\footnotetext{
${ }^{1}$ The data were gently made available by the coordinator of the project ALPI - Elaboración y edición de los materiales del Atlas Lingüístico de la Península Ibérica (CSIC), Pilar García Mouton, and by the Portuguese coordinator, João Saramago.
} 
totalize approximately 600,000 words. The recordings were selected from enquiries conducted for geolinguistic projects between 1974 and 2004. We have taken into account data obtained for gerunds and for possessives without determiners in two previous studies that used CORDIAL-SIN as a source (Lobo 2008 and Carrilho \& Pereira 2011). For the verbal forms in -ra, the data were obtained through a Concordancer program that runs on the POS annotated files (Concordance 3.3, July 2009 @R.J.C.Watt 1999-2009).

By comparing the data obtained for three different morphosyntactic phenomena in these two different sources we intend to evaluate the relevance of each method and their complementarity for the study of dialect syntax. In the next section, we consider each of the phenomena.

\section{Three morphosyntactic phenomena}

\subsection{Gerunds}

\subsubsection{Variation in gerunds}

Portuguese gerunds are non-finite verbal forms in which the suffix -ndo attaches to the verb stem (root followed by theme vowel):
(1) verb stem + -ndo:
cantando bebendo dormindo singing drinking sleeping

There is dialectal variation in the use of gerunds, concerning their syntactic distribution, inflectional morphology, types of connectives that introduce gerund clauses and word order in gerund clauses. 
Dialectologia. Special issue, V (2015), 141-166.

ISSN: 2013-2247

\subsubsection{Syntactic distribution}

In the standard variety, gerunds may be found mainly in adverbial adjunct clauses, with a temporal, conditional, concessive, manner or causal meaning (2), and with some aspectual auxiliaries (3):

(2)

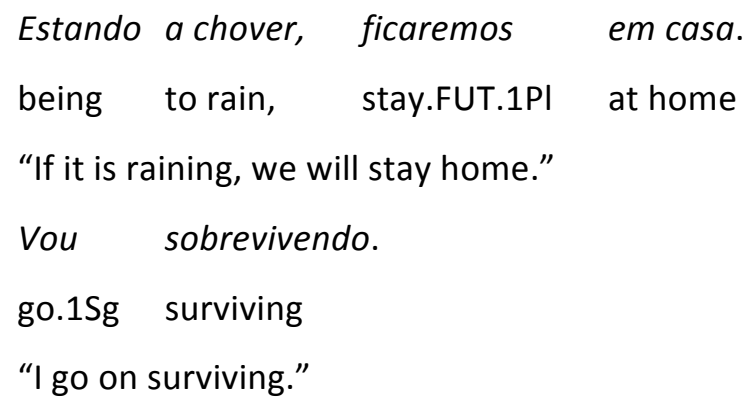

In non-standard varieties of European Portuguese and in the Brazilian variety, gerunds can also occur in the progressive, with the auxiliary estar 'to be' (4), with other aspectual auxiliary verbs (5), as complements to perceptive verbs (6), as secondary predicates (7), and in coordinated small clauses (8). In all these cases, we would find the variant with $a($ to $)+$ infinitive in the standard variety:

(4) Estou escrevendo um livro.

am.1Sg writing a book

"I am writing a book."

(5) O cão começou coxeando.

the dog started limping

"The dog started to limp."

(6) Orapaz ouviu ocão ladrando.

the boy heard the dog barking

"The boy heard the dog barking."

(7) Metia-se a água fervendo namurta.

put-SE the water boiling in.the myrtle

"One poured the water boiling on the myrtle." 
(8)

$$
\begin{aligned}
& \text { Ele cantando e eu dançando. } \\
& \text { he singing and I dancing }
\end{aligned}
$$

\subsubsection{Inflectional morphology}

In the standard variety of European Portuguese, gerunds are morphologically invariable. In some non-standard varieties, however, gerunds may inflect for person, displaying agreement morphology with the subject (Mota 1997; Lobo 2008, i.a.). Overt agreement morphemes only show up for plural and second singular persons, similarly to inflected infinitives.

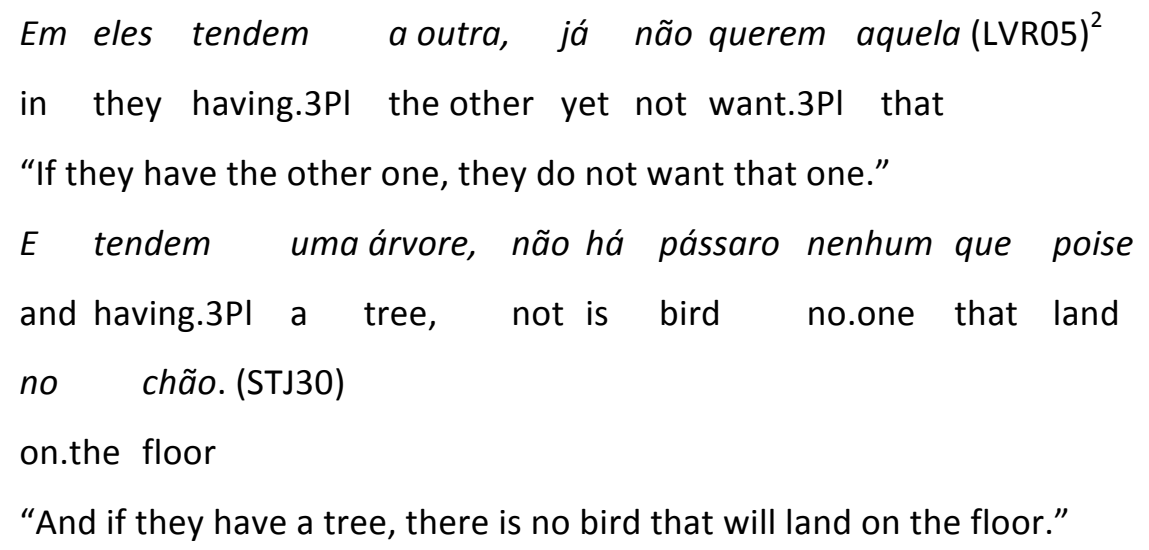

\subsubsection{Connectives}

In the standard variety, adverbial gerund clauses are usually not introduced by any connective, and may marginally be introduced by the connective em 'in'. In nonstandard varieties, one may find gerund clauses introduced by different connectives, including connectives that typically introduce finite domains, such as quando 'when', se 'if' (Lobo 2001, 2008):

\footnotetext{
2 The indicated sources for the CORDIAL-SIN examples are available at: http://www.clul.ul.pt/en/resources/412-cordial-corpus-verbatim-transcription.
} 
Dialectologia. Special issue, $\boldsymbol{V}$ (2015), 141-166.

ISSN: 2013-2247

Mas agente, em tendo saúde, trabalho não mata

but the people in having health work not kill

ninguém. (AAL35)

nobody

"But if one is healthy, work does not kill anybody."

(12)

Tomas outra nova vida quando um ano se passando. (MLD35)

take.2Sg other new life when a year SE passing

"You gain a new life when a year goes by."

\subsubsection{Word order}

Finally, in the standard variety of European Portuguese, there is obligatory subject-verb inversion in gerund clauses. In non-standard varieties, in contrast, we may find either subject-verb or verb-subject word orders (Lobo 2003, 2008; Fiéis \& Lobo 2011):

eles tendem as coisas em casa, fazem a toda a hora (AAL36)

they having.3PI the things at home, do.3PI at all the time

"If they have their stuff at home, they do it all the time"

A gente podendo-se defender, não há nada melhor. (MLD03)

the people might.GER-SE defend not exists nothing better

"If we can defend ourselves, there is nothing better."

Tomas outra nova vida quando um ano se passando. (MLD35)

take.2Sg other new life when a year SE passing

"You gain a new life when a year goes by."

\subsubsection{Comparing sources}

\subsubsection{Distribution of gerunds in CORDIAL-SIN}

In the dialect corpus the occurrences of inflected gerunds (16) are only found in one locality of the Azores and in the southern varieties, as shown in Map 1. The corpus 
allows us to conclude that inflected gerunds are mainly found in adjunct clauses and in parenthetical clauses, and (almost) absent from verbal domains selected by auxiliaries (Lobo 2008).
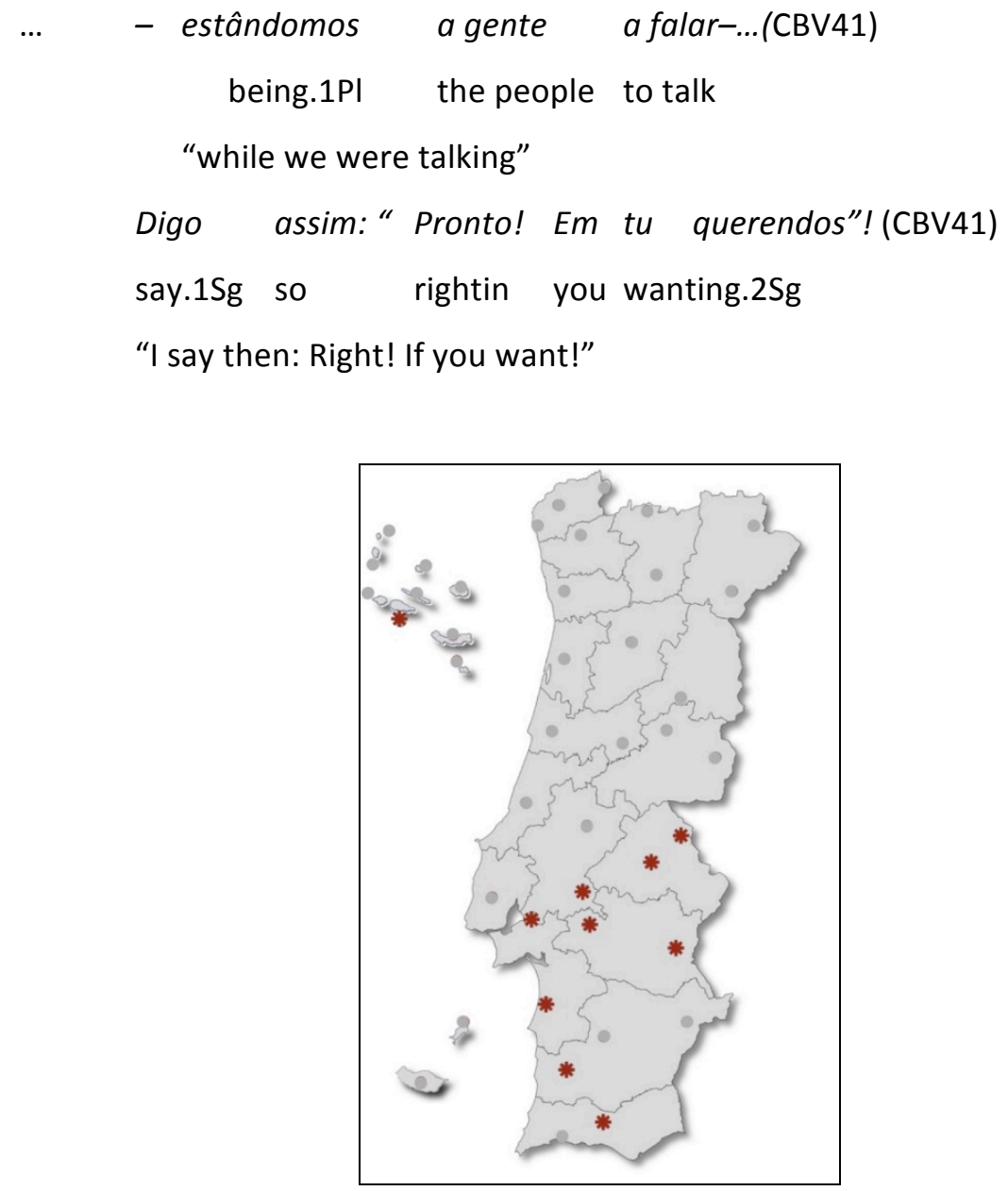

Map 1. Distribution of inflected gerunds (adapted from Lobo 2008)

Gerunds in progressive structures, with the auxiliary verb estar 'be' are found in southern varieties, in the islands (Azores and Madeira) and in one border location close to Galicia, as shown in Map 2 (adapted from Carrilho \& Pereira 2011). 
Dialectologia. Special issue, $\boldsymbol{V}$ (2015), 141-166.

ISSN: 2013-2247

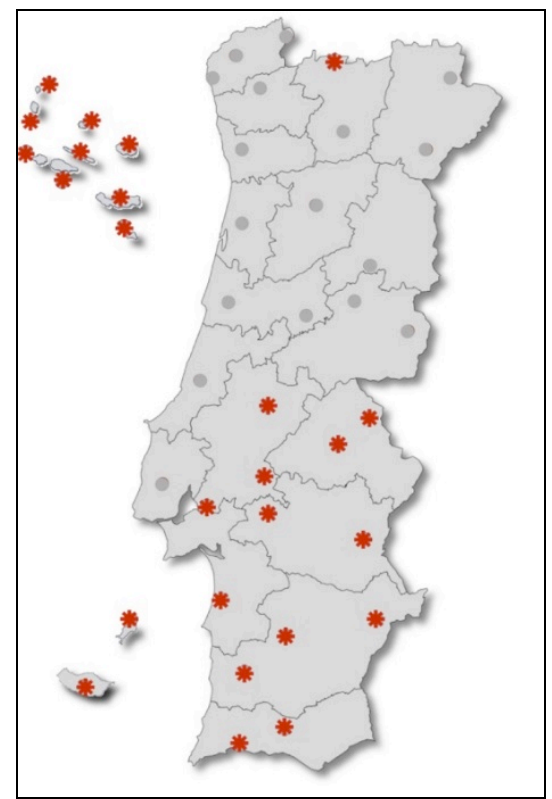

Map 2. Distribution of gerunds in progressive structures

While in these varieties we find the gerund (18a) and (19a) in these contexts, in the standard and northern varieties, we would find $a$ 'to' + infinitive in the same context, as shown in (18b) and (19b):

a. Estão ardendo. (PAL36)

are burning

b. Estão a arder.

are to burn

"They are burning."

(19)

a. Essa pessoa estava varrendo. (LUZ30)

that person was sweeping

b. Essa pessoa estava a varrer.

that person was to sweep

"That person was sweeping."

3.1.2.2 Distribution of connectives in gerund clauses in CORDIAL-SIN

In the dialect corpus, gerund clauses may be introduced by different types of connectives. The most frequent is em 'in', which can be found across the territory, but 
we can also find gerund clauses introduced by connectives that are typical of finite domains, such as quando 'when', se 'if', caso 'if' and other connectives that are not found in the standard variety, such as em bem 'in well'.

Em bem lhe partindem a casa, elas morrem. (CBV72)

in well him braking.3PI the house, they die.3PI

"When you break their house, they die."

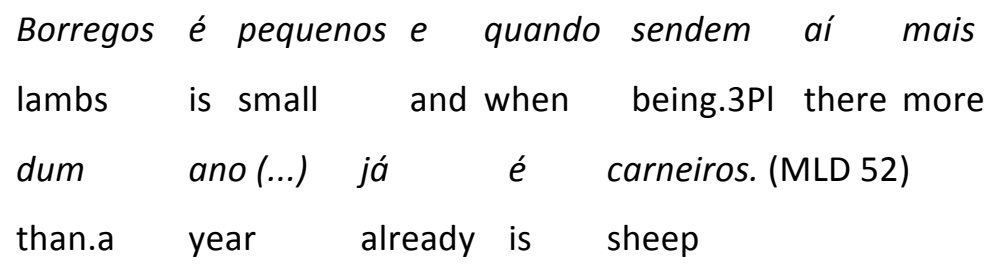

"(We call them) lambs when they are small, and when they are older than a year it's already sheep."

(22)

Isto os arrendamentos, já se sabe, que não há

this the rentings, already SE knows, that not has

como as coisas estandem nas mãos dosdonos

as the things being.3PI in the hands of the owners

"The rentings, you know, there is no such thing as they being in the hands of their owners."

The frequency of each connective in the localities with inflected gerunds is given in Table 1: 
Dialectologia. Special issue, $\boldsymbol{V}$ (2015), 141-166.

ISSN: 2013-2247

\begin{tabular}{|c|c|c|}
\hline Connective & $\begin{array}{l}\text { Localities with the } \\
\text { inflected gerund }\end{array}$ & $\begin{array}{l}\text { Localities without the } \\
\text { inflected gerund }\end{array}$ \\
\hline \multirow{2}{*}{ em 'in' } & $66 / 235$ & $101 / 274$ \\
\hline & $28 \%$ & $36 \%$ \\
\hline \multirow{2}{*}{ quando 'when' } & $47 / 235$ & $1 / 274$ \\
\hline & $20 \%$ & $0,4 \%$ \\
\hline \multirow{2}{*}{ em bem 'in well' } & $7 / 235$ & \\
\hline & $3 \%$ & 0 \\
\hline \multirow{2}{*}{ bem 'well' } & $4 / 235$ & $1 / 274$ \\
\hline & $1,7 \%$ & $0,4 \%$ \\
\hline \multirow{2}{*}{ caso 'if' } & $1 / 235$ & \\
\hline & $0,4 \%$ & 0 \\
\hline \multirow{2}{*}{ se 'if' } & 0 & $2 / 274$ \\
\hline & U & $0,7 \%$ \\
\hline \multirow{2}{*}{ onde/donde 'where' } & $1 / 235$ & $1 / 274$ \\
\hline & $0,4 \%$ & $0,4 \%$ \\
\hline \multirow{2}{*}{ como 'how' } & $1 / 235$ & 0 \\
\hline & $0,4 \%$ & U \\
\hline
\end{tabular}

Table 1. Frequency of connectives introducing adverbial gerund clauses in the 10 localities with inflected gerunds and in the 31 localities without inflected gerunds

Map 3 illustrates the distribution of each connective of gerund clauses across Portugal.

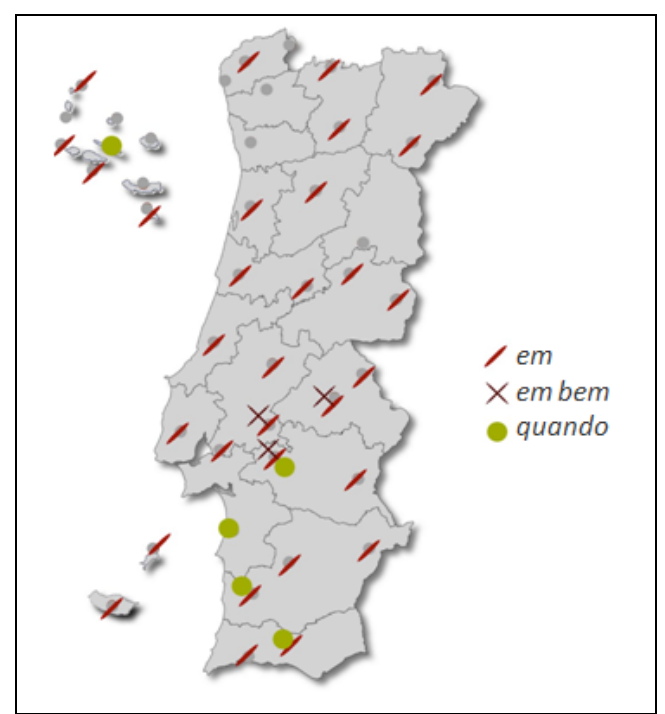

Map 3. Distribution of connectives of gerund clauses 
As can be seen, while gerund clauses with em are common across the country, gerund clauses with quando and em bem are found in the geographic area where inflected gerunds can be found. Overall adverbial gerund clauses are more frequent in the southern and insular varieties, where inflected gerunds can be found (there are 274 gerund adverbial clauses in the 31 localities without inflected gerunds, while there are 235 adverbial gerund clauses in the 10 localities with the inflected gerund).

When we consider word order in adverbial gerund clauses, the CORDIAL-SIN data allow us to see that the presence of the inflection does not have a clear effect on word order. In Portuguese dialects, both Subject-Verb and Verb-Subject word orders can be found, unlike what happens in the standard variety (Lobo \& Fiéis 2015).

\begin{tabular}{ccc}
\cline { 2 - 3 } & $\begin{array}{c}\text { Localities with } \\
\text { inflected gerunds }\end{array}$ & $\begin{array}{c}\text { Localities without } \\
\text { inflected gerunds }\end{array}$ \\
\hline \multirow{2}{*}{ Su-V } & 42 & 35 \\
& $64 \%$ & $60 \%$ \\
V-Su & 24 & 23 \\
& $36 \%$ & $40 \%$ \\
\hline Total & 66 & 58 \\
\hline
\end{tabular}

Table 2. Proportion of subject-verb and verb-subject word orders in adverbial gerund clauses

\subsubsection{Gerunds in the ALPI}

The morphosyntactic questionnaire of ALPI does not include questions that favour the occurrence of inflected gerunds. The three questions that include gerunds (Table 3) are all third singular person contexts and they do not include peripheral adjunct clauses, the ones where inflected gerunds are more common. Furthermore, only Q. 352 presents a context subject to variation between the gerund and $a+$ infinitive. Therefore, the relevance of these questions for dialect variation in Portuguese is rather limited, since the crucial linguistic contexts have not been included in the questionnaire. 
Dialectologia. Special issue, $\boldsymbol{V}$ (2015), 141-166.

ISSN: 2013-2247

\begin{tabular}{ccl}
\hline Q.Nb & Page & Question \\
\hline 326 & 22 & $\begin{array}{l}\text { Todo se alcanza teniendo paciencia } \\
\text { Tudo se alcança tendo paciência } \\
\end{array}$ \\
& "Everything is reached having patience" \\
\hline 327 & 22 & $\begin{array}{l}\text { Se puede vivir queriendo trabajar } \\
\text { Pode-se viver querendo trabalhar } \\
\end{array}$ \\
& "One can live wanting to.work" \\
& Al padre le vieron llorando \\
& O pai, viram-no a chorar \\
& "The father, (they) saw-him crying"
\end{tabular}

Table 3. Questions including gerunds in the ALPI

Nevertheless, question 352 allows us to conclude that the gerund variant in complements to perceptive verbs seems to be geographically more limited than in progressive contexts (Map 4, vs. Map 2 above).

Questions 326 and 327 allow us to map gerund clauses introduced by the connective em 'in' (Map 5). Comparing these results with Map 3 above, we can see that probably the kind of manner gerund clause considered in the ALPI questionnaire is not the preferential context for this kind of connective. The geographic distribution of em + gerund clauses is much more limited in the ALPI data. Gerund clauses with em occur only in five locations in these data: Montalegre (Vila Real); Reguengo (Portalegre); Povos (Lisboa); Ferreira do Alentejo (Beja); Monte dos Sapos (Beja). 


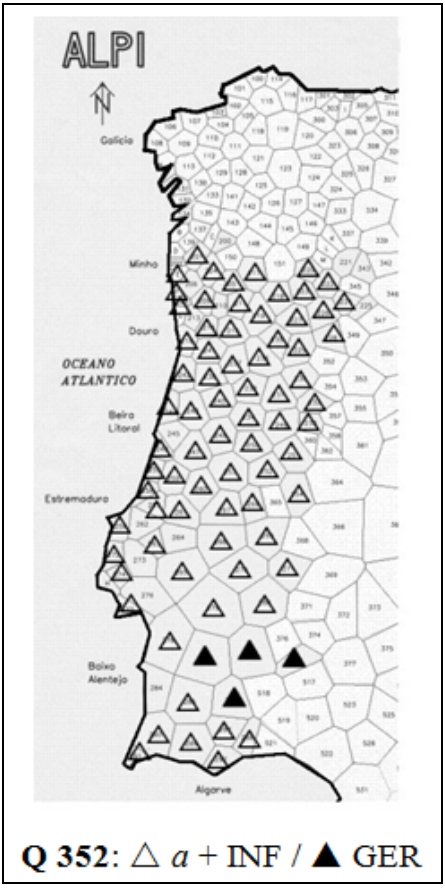

Map 4. Distribution of the variants gerund and $a+$ infinitive in complements to perceptive verbs, based on Q 352 from ALPI (from Carrilho \& Lobo 2012)

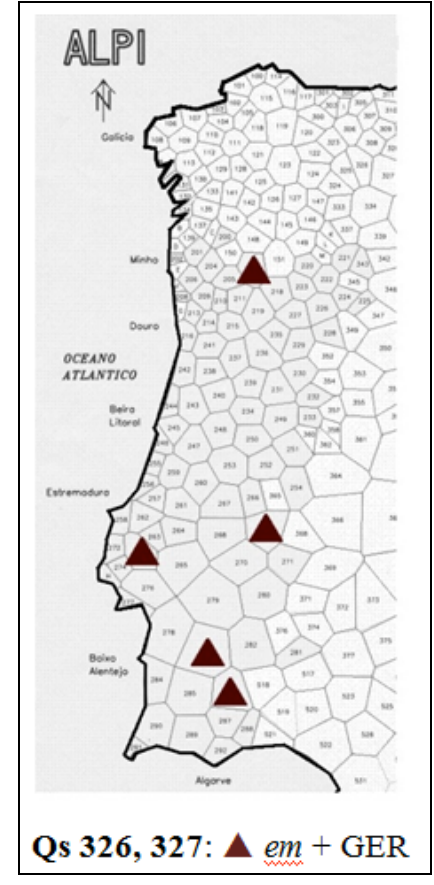

Map 5. Gerund clauses with connective em 'in', based on Q 326 and 327 from ALPI

\subsubsection{Summary}

Morphosyntactic variation in gerunds in Portuguese is attested in both sources. However, the corpus and the linguistic atlas provide different and, to some extent, complementary pictures concerning the geographical and linguistic distribution of the considered variants. While CORDIAL-SIN data lack certain contextual manifestations (namely, gerunds in complements to perceptive verbs, which by contrast are considered in the ALPI questionnaire), the geographical distribution of the relevant phenomena seems to be less restrained in the corpus (even though the CORDIAL-SIN network is less extended than the ALPI network). On the other hand, the ALPI data do not include important contexts for studying variation in gerunds, namely the combination with auxiliaries and gerunds in adjunct clauses. 
Dialectologia. Special issue, $\boldsymbol{V}$ (2015), 141-166.

ISSN: 2013-2247

\subsection{Determiner before possessives}

3.2.1. Variation in the occurrence of articles before prenominal possessives

One of the phenomena that is subject to intralinguistic and crosslinguistic variation is the presence of a determiner before a possessive (23a vs. 23b-e) (cf. i.a. Mattos e Silva 1989; Miguel 2002; Rinke 2010). In the history of Portuguese there was a gradual change towards a higher frequency of determiners before possessives. In the Brazilian Portuguese variety, the absence of the determiner is nowadays the most frequent variant (23b), although, there is still variation, mostly dependent on geographic and stylistic variables (Callou 2008). ${ }^{3}$ In Modern European Portuguese, the standard variant corresponds to the article before the possessive (23a).
a. Os meus livros EP the my books
b. meus livros BP my books
c. mis libros Spanish
d. mes livres French
e. my books
English

We can still find variation in Modern EP, however, in contexts with kinship nouns. There is thus lexical conditioning in non-standard varieties of EP for the absence of the determiner before possessives. Variation between the presence or absence of the determiner before possessives is displayed only with this semantic subclass of nouns:

\footnotetext{
${ }^{3}$ According to Callou (2008), the article is still preserved in the southern regions of São Paulo and Porto Alegre (with a higher frequency in written registers), is mostly absent in the north-east regions of Recife and São Salvador, and Rio de Janeiro is in an intermediate position.
} 
(24)
a. o meu pai
the my father
b. meu pai
my father

\subsubsection{Comparing sources}

3.2.2.1. Absence of the determiner before possessives in CORDIAL-SIN

A search in the dialectal corpus shows that the article may be absent in nonstandard varieties before possessives that precede kinship nouns, as shown in (25)(28):

(25) E minha tia lia aqueles livros. (GRJ06) and my aunt read those books

"And my aunt read those books."

(26) Olha, fala com teu avô [...] (CTL18) look talk with your grandfather "Look, talk to your grandfather"

(27) Olhe, só tive minhasirmãs à noite que me ajudaram look, only had my sisters at night that me helped a lavar as tripase não tive mais ninguém. (PIC29) to wash the guts and not had more no one "Look, I only had my sisters that helped me at night washing the guts and I had no one else."

(28) Masmeu pai tinha era gado, fazendas [...]. (PST25)

but my father had was cattle, farms

"But what my father had was cattle and farms" 


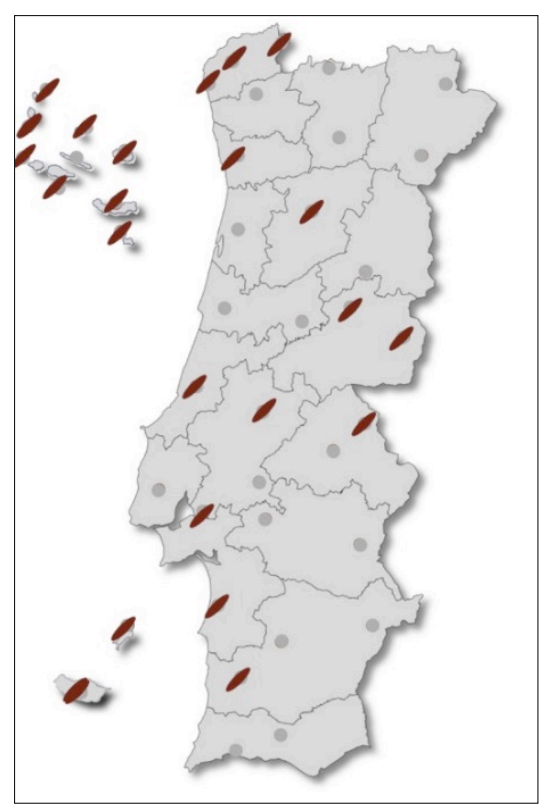

Map 6. Distribution of the absence of determiner before possessive with kinship nouns

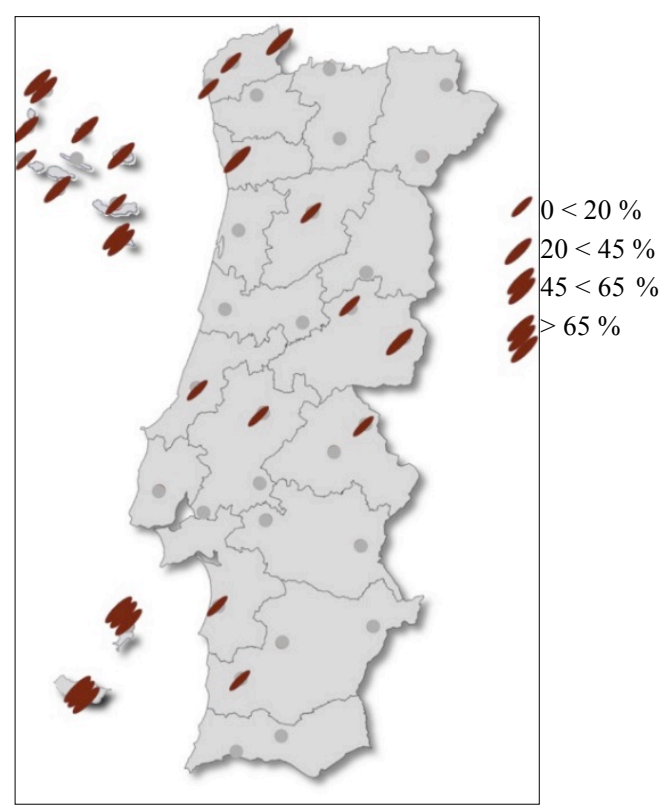

Map 7. Frequency of the absence of determiner before possessive with kinship nouns

Although the absence of determiner can be found across Portugal (both mainland and islands), when we look at the frequency of the non-standard variant, we observe that it has much higher rates in the islands, particularly in Madeira (as shown in Maps 6 and 7, from Carrilho \& Pereira 2011).

\subsubsection{Absence of the determiner before possessives in ALPI}

The morphosyntactic questionnaire of ALPI includes four questions that have preverbal possessives (Table 4). However, only three of them have kinship nouns. The data from question number 261 , the only one that does not have a kinship noun, have been studied and mapped by Fernández-Ordóñez (2011). 


\begin{tabular}{|c|c|c|}
\hline Q. Nb & Page & Question \\
\hline \multirow[t]{3}{*}{260} & 17 & Mis cuñados y mis primos \\
\hline & & Os meus cunhados e os meus primos \\
\hline & & "My brothers-in-law and my cousins" \\
\hline \multirow[t]{3}{*}{261} & 18 & Sus corderos están en nuestro prado \\
\hline & & Os seus cordeiros estão no nosso campo \\
\hline & & "His lambs are in our field" \\
\hline \multirow[t]{3}{*}{394} & 29 & Siembra para que coma su familia \\
\hline & & Semeia para a sua família comer \\
\hline & & "He sows for his family to eat" \\
\hline \multirow[t]{3}{*}{403} & 29 & Abandonaran a su tío \\
\hline & & Abandonaram o seu tio \\
\hline & & "They abandoned their uncle" \\
\hline
\end{tabular}

Table 4. Questions including preverbal possessives in the ALPI

As can be seen in Map 8, the area corresponding to possessives preceded by determiners covers the whole Portuguese territory.

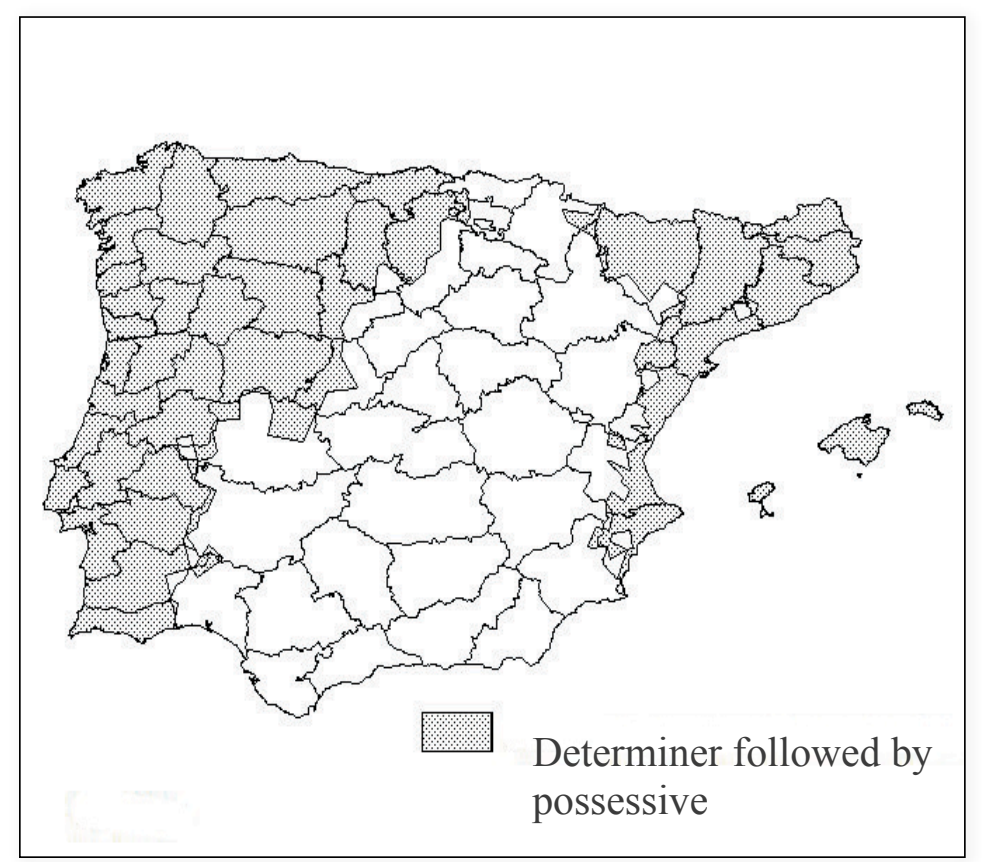

Map 8. Determiner followed by possessive, based on Q 261 from ALPI (from Fernández-Ordóñez 2011: 52, map 28) 
For the other three questions, we can find variation in the presence of the determiner, as can be seen in Map 9.

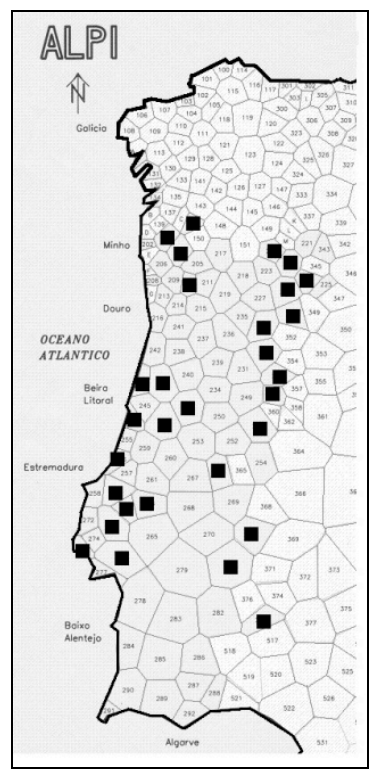

Map 9. Absence of determiner before possessive, based on Qs 260, 394, 403 from ALPI

Although ALPI does not include data for the islands, the locations where the absence of the determiner was found in the continental territory show a fairly similar distribution as the localities where the same phenomenon was found in the CORDIALSIN data - western border, Minho and central coast (compare with Maps 6-7).

\subsection{Verbal forms ending in -ra}

3.3.1. Variation in the distribution of verbal forms ending in -ra

Verbal forms ending in -ra may have different values. They may refer to an event that occurred in the past prior to a past event, corresponding to the pluperfect (maisque-perfeito). This usage is available in the standard variety and can alternate with the verbal complex with the auxiliary ter 'have' in the imperfect followed by the past participle of the main verb: 
(29)
a. Quando a campainha tocou, ela já terminara
when the bell rang, she already finish.PPF
"When the bell rang, she had already finished."
b. Quando a campainha tocou, ela já tinha terminado
when the bell rang, she already had finished
"When the bell rang, she had already finished."

They may also occur in conditional clauses ((30a), (31a)), as a variant to the imperfect subjunctive (imperfeito do conjuntivo) ((30b), (31b)), similarly to what happens in Spanish where both forms are traditionally classified as imperfect subjunctive (Rojo \& Veiga 1999):

a. Tivera eu menos vinte anos, tudo seria diferente.

have.ra I less twenty years, all would.be different

b. Tivesse eumenos vinte anos, tudo seria diferente

have.IMPSBJI less twenty years all would.be different

"If I was twenty years younger, everything would be different."

a. Se fora charrueco, era o mesmo. (SRP09)

if be.raplough was the same

b. Sefosse charrueco, era o mesmo.

if be.IMPSBJ plough was the same

"If it was a plough, it would be the same."

In non-standard varieties, some modal verbs (haver de 'have to' and dever 'must/should'), as well as the volitional verb querer 'to want'can also bear the -ra ending ((32a), (33a), (34a)), and in this case they are equivalent to the imperfect indicative or the conditional in the standard variety ((32b), (33b), (34b)):

a. Eu não devera de ter ido apanhar tomate. (STJ02)

I not should of have gone pick tomato

b. Eu não devia/deveria ter ido apanhar tomate.

I not should have gone pick tomato

"I shouldn't have gone to pick tomatoes." 
Dialectologia. Special issue, V (2015), 141-166.

ISSN: 2013-2247

a. que aquilo que havera de cair por si. (CLH17)

that that.thing that had to fall by itself

b. que aquilo que havia/haveria de cair por si. that that.thing that had/would.have to fall by itself

"that that thing would have fallen by itself

(34)

a. Eu quisera ser rico.

I wanted to.be rich

b. Eu queria ser rico.

I wanted to.be rich

"I wanted to be rich."

Verbal forms ending in -ra can also occur in some exclamative contexts with a counterfactual value (35a). In the same context, we can find the pluperfect subjunctive (auxiliary ter 'have' in the imperfect subjunctive followed by the past participle of the main verb) (35b).

a. Se não dá passada, comera! (STA19)

if not give step ate

b. Se não dá passada, tivesse comido!

if not give step had eaten

"If you do not walk, you should have eaten!"

Finally, verbal forms in -ra may occur in idiomatic expressions with a desiderative value (tomara and quem me dera):

(36) Tomara a gente saúde! (AJT32)

caught the people health

"We wish we were healthy."

(37) Quem me dera ter uns olhos assim. (MTV43)

Who me gave have some eyes so

"I wish I had eyes like that. 


\subsubsection{Comparing sources}

\subsubsection{Verbal forms in -ra in CORDIAL-SIN and in ALPI}

The morphosyntactic questionnaire of ALPI includes four questions that potentially induce verbal forms in -ra (Table 5). Three of them correspond to conditional clauses, in which there is variation in Spanish between the imperfect subjunctive in -ra or in -se.

\begin{tabular}{ccl}
\hline Q. Nb. & Page & Question \\
\hline 386 & 28 & $\begin{array}{l}\text { Si tuviera dinero lo compraría } \\
\text { Se tivesse dinheiro, comprava-o/comprá-Io-ia } \\
\end{array}$ \\
& "If I had money, I would buy it" \\
\hline 387 & 28 & Si estudiase aprendería \\
& Se estudasse, aprendia /aprenderia \\
& "If I studied, I would learn" \\
\hline 388 & 28 & Si pudiera la mataría \\
& Se pudesse matava-a/matá-la-ia \\
& "If I could, I would kill her" \\
\hline 389 & 28 & Yo quisiera ser rico \\
& Eu queria ser rico \\
& "I would like to be rich"
\end{tabular}

Table 5. Questions including potential contexts for verbal forms in -ra in the ALPI (three conditional clauses and a counterfactual modal context)

If we map the different verbal forms ending in -ra based on the dialect corpus and on the ALPI data, according to their contexts, we obtain the following maps:

As illustrated in Map 10, we find verbal forms in -ra with different values in CORDIAL-SIN, although they are not very productive overall, even for the pluperfect value. The uses corresponding to the pluperfect do not have a clear geographic distribution in the corpus data and can be found in four locations (two northern locations, one in the Azores and one in the south-east coast). As for modal verbs ending in -ra, we may observe that they are only found in the Azores and in two 
Dialectologia. Special issue, $\boldsymbol{V}$ (2015), 141-166.

ISSN: 2013-2247

localities of southern Portugal. In the corpus data, verbal forms in -ra corresponding to the imperfect subjunctive are only found in two locations near the western border with Spain.

In the ALPI data, the relevant questions rarely induced a verbal form in -ra: in conditional clauses there are only two occurrences of these forms in the central region - Almeirim (Santarém), Montemor-o-Velho (Coimbra) - for the questions analyzed by Mouzo Villar (2008), and two occurrences of -ra forms for Q. 389 that we analyzed Almeirim and Rio Maior (Santarém).
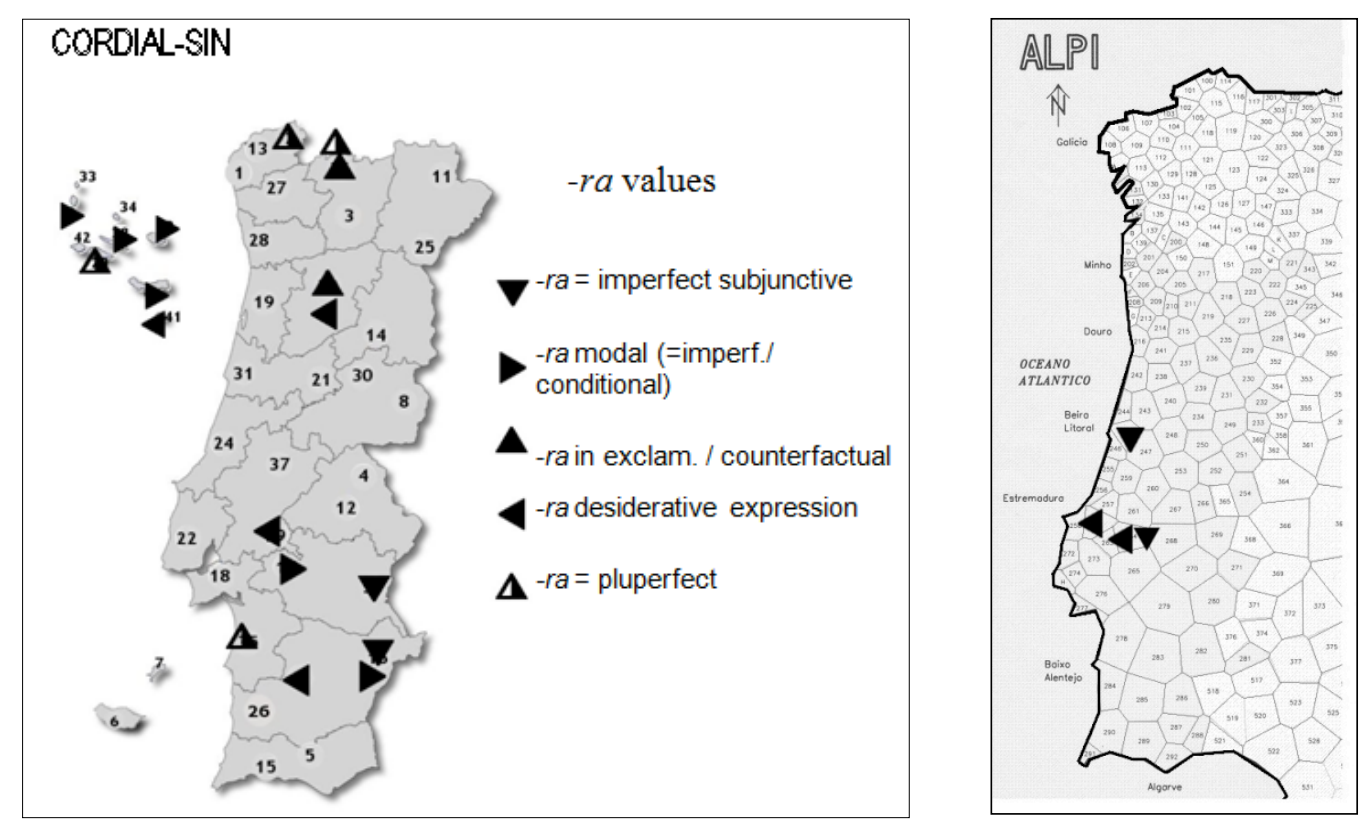

Maps 10 and 11. Occurrences of verbal forms ending in -ra according to context in CORDIAL-SIN and in ALPI (maps from Carrilho \& Lobo 2012)

In conditional structures, the predominant forms are imperfect subjunctives in -sse, as in the standard variety; for Q. 389, where the verbal form has a modal value, most responses contained an indicative imperfect (queria 'wanted'). The areas where the forms were registered in CORDIAL-SIN and in the ALPI data are not the same, although they are similar for the modal value. 


\section{Conclusions}

The three case studies we analyzed comparing data obtained from the dialect corpus and data obtained in responses to the ALPI questionnaire allow us to confirm the classical advantages and drawbacks of these two kinds of sources and to some extent their complementarity.

Direct or indirect questionnaires of atlases induce less spontaneous responses to morphosyntactic phenomena. This could explain to some extent the absence of nonstandard or regional variants. As for gerunds, for instance, the area where they (as a variant to $a+$ infinitive) were found in the ALPI data is much more restricted than in the CORDIAL-SIN data. Verbal forms in -ra also have a wider distribution in the corpus when compared to the ALPI data. A questionnaire allows, however, direct comparison between the different network points. The data obtained in the corpus show us that the questionnaire has to be carefully built so as to include the relevant contexts. This did not happen for all phenomena in the case of ALPI: crucial contexts of morphosyntactic variation in the Portuguese domain (gerunds with auxiliaries, peripheral gerund adverbial clauses) were not considered.

The corpus also has some limitations in what concerns the study of morphosyntactic phenomena. Some contexts may be absent just because they are not very frequent in spontaneous speech and did not show up in the particular discourse situation. We did not find gerunds following perceptive verbs in the corpus, for instance. The corpus allows us, however, to measure the productivity of the different structures and of linguistic variants and to carry a more detailed study of the syntactic distribution of linguistic forms. The study of the frequency of possessives without determiners in the corpus gave us important information on asymmetries in the use of the non-standard variant across the Portuguese territory.

We would like to conclude that a carefully built morphosyntactic questionnaire taking into account the relevant contexts is crucial for a better understanding of syntactic variation. As we have seen, the ALPI questionnaire does not include fundamental morphosyntactic variables for the Portuguese domain. In that respect, the corpus data give us a general picture of relevant morhosyntactic phenomena and 
Dialectologia. Special issue, $\mathbf{V}$ (2015), 141-166.

ISSN: 2013-2247

are thus extremely important to serve as the basis for the preparation of a more accurate morphosyntactic questionnaire.

Finally, we would like to highlight that, in spite of the traditional problems encountered when analyzing both sources, in general the data obtained from the corpus and from the ALPI questionnaire are quite consistent: both sources show a lexical conditioning in the absence of determiner before possessive and a southern distribution of gerund forms in verbal periphrases and complements to perceptive verbs (although, since the atlas does not include the islands, some important nonstandard morphosyntactic phenomena are not sufficiently represented).

To conclude, we would like to stress the importance of taking into account different sources when studying morphosyntactic variation. The data obtained from the corpus and from the responses to the ALPI questionnaire complemented each other.

\section{References}

CAllou, D. (2008) "Gramática, variação e normas", in S. Rodrigues Vieira \& S. Figueiredo Brandão (orgs.), Ensino de gramática: descrição e uso, São Paulo: Contexto, 13-29.

CARRILHO, E. \& M. Lobo (2012) "Contribution à l'étude de la variation syntaxique dans le domaine ibéroroman", in M. Oliviéri, G. Brun-Trigaud \& Ph. Del Giudice (eds.), La Leçon des dialectes. Hommages à Jean-Philippe Dalbera, Alessandria: Edizioni dell'Orso, 323336.

CARRILHO, E. \& S. PEREIRA (2011) “Sobre a distribuição geográfica de construções sintácticas nãopadrão em Português europeu", in Textos Seleccionados do XXVI Encontro Nacional da Associação Portuguesa de Lingüística, CD-ROM, Lisboa: APL, 125-139. [http://www.apl.org.pt/docs/26-textos-seleccionados/Carrilho_Pereira.pdf].

Fernández-ORdoñez, I. (2011) La lengua de Castilla y la formación del español, Madrid: Real Academia Española.

FIÉlS, A. \& M. LOBo (2011) “Aspectos da sintaxe das orações gerundivas no Português Medieval e no Português Europeu Contemporâneo", in Textos Seleccionados. XXV Encontro Nacional da Associação Portuguesa de Lingüística, Porto: APL, 419-434. 
García Mouton, P., D. Heap \& M.-P. Perea (2012) "The Present and the Future of the Atlas Lingüístico de la Península Ibérica (ALPI)", Dialectologia. Special Issue, III, 1-6. [http://www.publicacions.ub.edu/revistes/dialectologiaSP2012].

Loвo, M. (2001) “On Gerund Clauses of Portuguese Dialects”, in A.Veiga, V. M. Longa \& J. D. Anderson (eds.), El Verbo. Entre el Léxico y la Gramática, Lugo: Ed. Tris Tram, 107-118.

LoBo, M. (2003) Aspectos da Sintaxe das Orações Subordinadas Adverbiais do Português, PhD Dissertation. Universidade Nova de Lisboa.

LOBO, M. (2008) "Variação morfo-sintáctica em dialectos do português europeu: o gerúndio flexionado", Diacrítica, 22.1, 25-55.

LOBO, M. \& A. FIÉIS (2015) “Ordem de palavras em orações gerundivas do português". Paper presented at the 'Simpósio Gramática, Variação e Mudança'. Gallaecia. III Congresso Internacional de Linguística Histórica. Santiago de Compostela.

MAtTOS E SILVA, R. V. (1989) Estruturas trecentistas: Elementos para uma gramática do Português Arcaico, Lisboa: Imprensa Nacional - Casa da Moeda.

Miguel, M. (2002) "Possessive pronouns in European Portuguese and Old French", Journal of Portuguese Linguistics, 2, 214-240.

MotA, M. A. (1997) "Les traits nombre et personne/nombre en portugais - l'oral dans ses variétés", in M. Bilger, K. van den Eynde \& F. Gadet (eds.), Analyse Linguistique et approches de l'oral. Recueil d'études offert en hommage à Claire Blanche-Benveniste, Orbis/Supplementa, Tome 10, Leuven-Paris: Peeters, 339-345.

Mouzo VILLAR, R. (2008) “Análise contrastiva entre galego e portugués: as oracións condicionais no ALPI", in Textos Seleccionados. Encontro Nacional da Associação Portuguesa de Lingüística, Lisboa: APL, 589-596. [http://www.apl.org.pt/docs/24-textosseleccionados/40-Villar.pdf].

RINKE, E. (2010) "A combinação do artigo definido e pronome possessivo na história do português", Estudos Lingüística Galega, 2, 121-139.

Rojo, G. \& A. VeIGA (1999) “El tiempo verbal. Los tiempos simples”, in I. Bosque \& V. Demonte (orgs.), Gramática Descriptiva de la Lengua Española, vol. II, Madrid: Espasa, 2867-2934. 